\title{
A regional perspective on the spatial concentration in Romania's international trade in 2011
}

\author{
Stângaciu Oana Ancuţa, PHd, "Vasile Alecsandri” University of Bacău, Romania
}

\begin{abstract}
In this study, I aimed at analyzing the territorial structure of the international trade in Romania in 2011 on the level of each development region. Starting from the values of the export and import trade flows pertaining to each region of Romania and using statistical methods of analysis, we processed the existing data in order to determine the distribution of foreign trade and to emphasize the regional poles of competitiveness from this point of view. Since other indexes, such as the trade balance or the import/export coverage ratio, are also marks of competitiveness and of the increase or decrease in the performance of a certain economy, we also calculated these indexes for each region of the country. In order to statistically substantiate the existence of a certain degree of spatial concentration of the Romanian international trade in different regions of the country, we resorted to the boxplot graphical representation and to the Gini square and the Gini index respectively.
\end{abstract}

\section{Key words}

FOB export, CIF import, trade balance, the import/export coverage ratio, spatial concentration, boxplot, the Gini index

\section{The JEL classification}

C10, F10, F49, O11

\section{Introduction}

When Romania joined the European Union, the statistics referring to the international trade in goods were established by adding the data from the Intrastat (trade within the EU) and the Extrastat (trade outside the EU) statistic systems.

The INTRASTAT system was created and developed within the European Union, being operated in Romania by the National Institute of Statistics, in order to collect data directly from the business operators in the member states which exchange goods with other member states of the European Union, while the EXTRASTAT system is operated by the National Customs Authority, since it is the institution that collected and processed the customs declarations, and the level of the imports and exports between Romania and other countries outside the European Union was established based on these declarations. ${ }^{1}$

The statistics for Romania's foreign trade are made up according to the methodology used on international level and according to this methodology the data collected for 2011 is provisional data.

\footnotetext{
${ }^{1}$ The Romanian International Trade Yearbook, the National Institute of Statistics, Bucharest, p. 8
} 


\section{Romania's FOB exports}

Romania's FOB exports in 2011 were of 45,040,813 thousand euro, the top 3 regions, with exports of over 7 billiard, are: Bucharest Ilfov with 8,931,805 thousand Euro, which is $19.9 \%$ of the total exports of country, South Muntenia with 7,617,899 thousand Euro (17.0\% of the total exports of the country) and the North-West region with 7,025,639 thousand Euro ( $15.7 \%$ of the total exports of country).

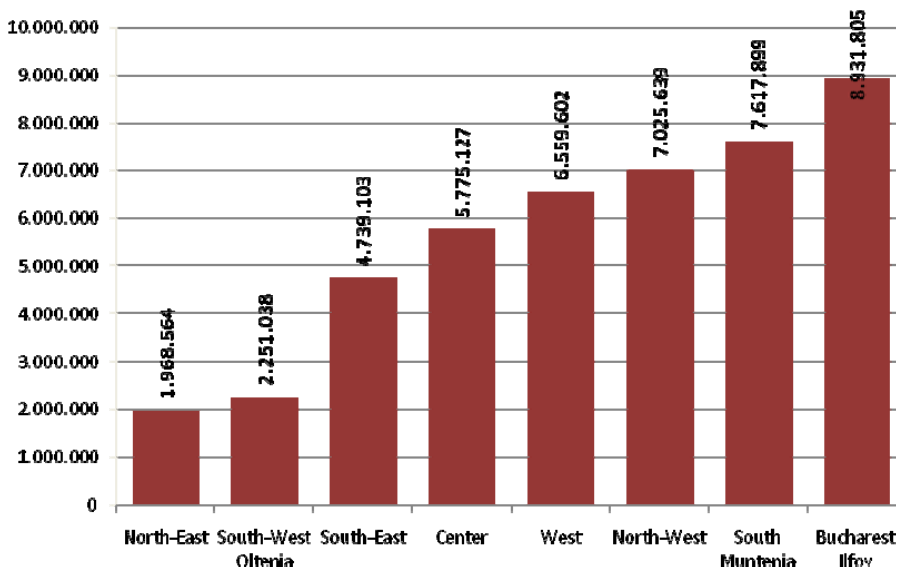

Figure 1. FOB exports for each development region in 2011 Source: processing of the data offered by DJS Bacau

At the middle of the classification are listed 3 other regions which exported goods amounting between 4 and 7 billion euro: the West region with 6,559,602 thousand Euro representing $14.6 \%$ of the total exports of the country, the Central region with 5,775,127 thousand Euro $(12.9 \%$ of the total exports of the country) and the South-East with 4,739,103 thousand Euro (10.6\% of the total exports of the country), while on the last 2 places, far behind the other regions, with exports lower than 2.5 billion euro, are the following regions: South-West Oltenia with $2,251,038$ thousand Euro (5.0\% of the total exports of the country) and NorthEast with 1,968,564 thousand Euro (4.44\% of the total exports of the country).

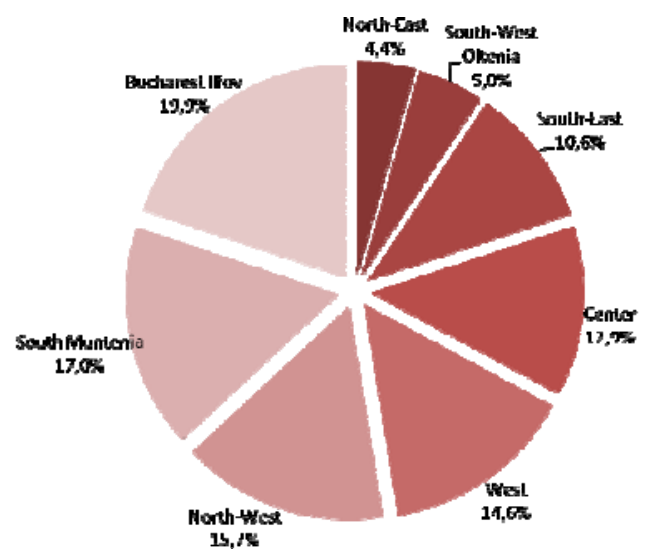

Figure 2. The structure of exports for each development region in 2011 (\%)

Source: processing of the data offered by DJS Bacau 


\section{Romania's CIF imports}

Romania's CIF imports in 2011 reached the amount of 54,823,559 thousand Euro. The region Bucharest-Ilfov is placed once again on top of the regions with the largest amount of imports: 20,409,827 thousand Euro, which represents $37.3 \%$ of the total imports in Romania, being followed by 2 other regions which import goods amounting to about 6.5 billion euro: the North-West with $6,883,851$ thousand Euro has $12.6 \%$ of the total amount of imports and South Muntenia with $6,352,269$ thousand Euro, which is $11.6 \%$ of the total amount of imports.

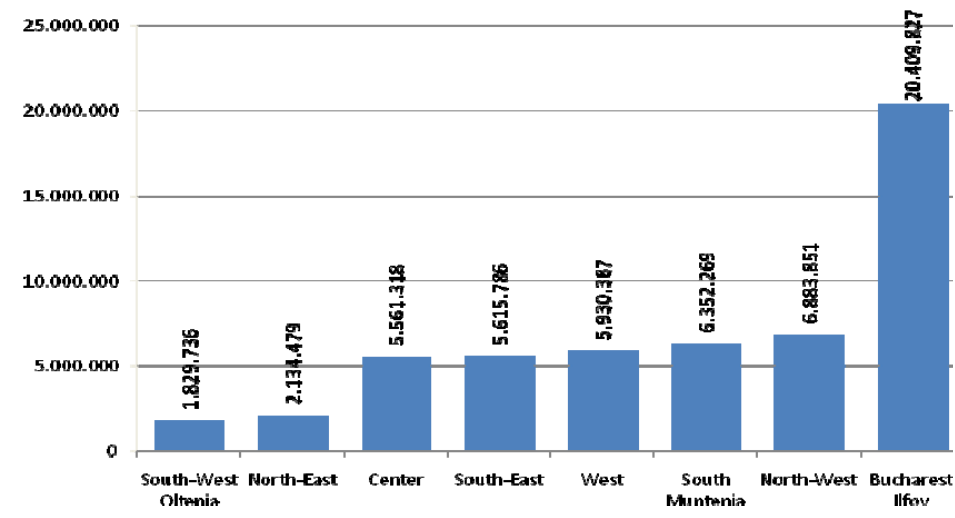

Figure 3. CIF imports for each development region in 2011 Source: processing of the data offered by DJS Bacau

3 other regions, with a value of imports amounting to about 5.5 billion euro, each recording over $10.0 \%$ of the total imports in the country, are listed at the middle in the hierarchy of the regions: the West region with 5,930,387 thousand Euro which represents $10.8 \%$ of the total imports in the country, the South-East with 5,615,786 thousand Euro $(10.3 \%$ of the total imports in the country) and the Central region with 5,561,318 thousand Euro (10.2\% of the total imports in the country). With percentages of under $4.0 \%$ of the total imports are the North-East region with 2,134,479 thousand Euro (3.9\% of the total imports in the country) and South-West Oltenia with $1,829,736$ thousand Euro $(3.3 \%$ of the total imports in the country), the two of them being situated on the last places in the classification.

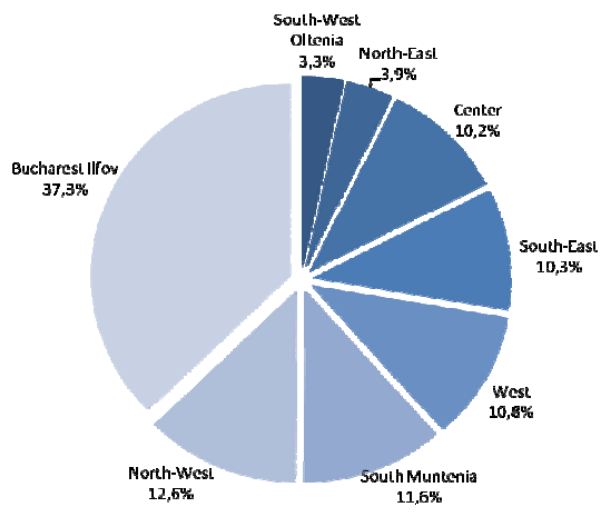

Figure 4. Structure of the imports in each development region in 2011(\%)

Source: processing of the data offered by DJS Bacau 


\section{The trade balance and the import/export coverage ratio}

All the export and import relationships of Romania with the rest of the world are better underlined in the trade balance, by calculating the balance of the foreign trade operations. Calculating this balance of the international trade operations (FOB-CIF) involved determining the difference between the exports materialized in the FOB prices and the imports materialized in CIF.

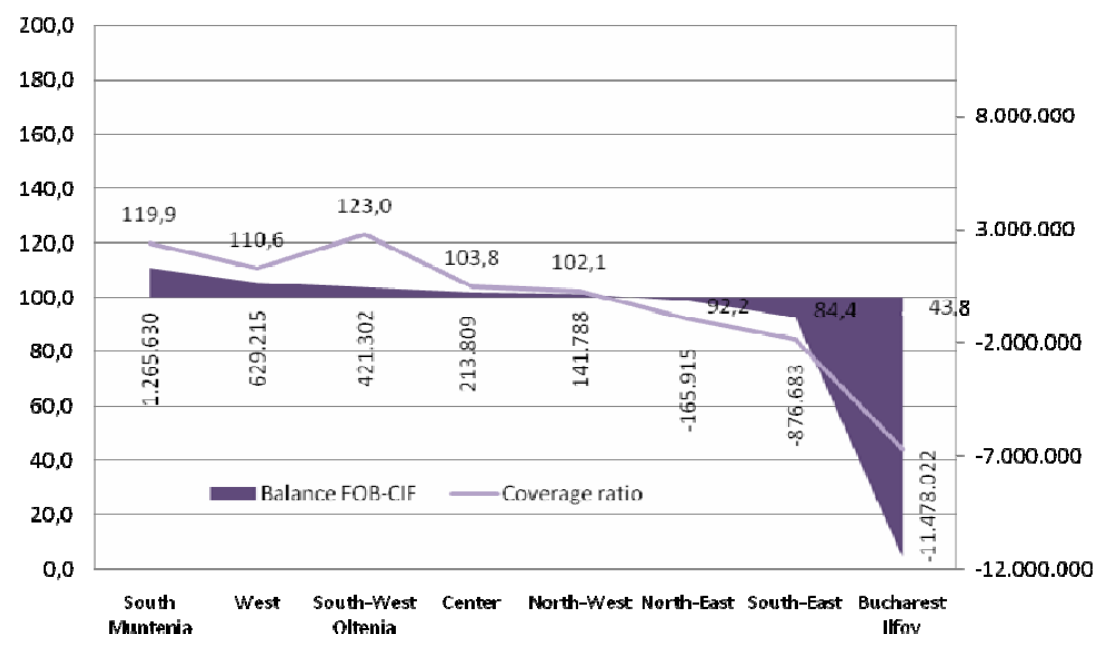

Figure 5. The balance of the FOB-CIF international trade operations (in thousands of euro) and the FOB-CIF coverage ratio (\%) for each development region in 2011

Source: processing of the data offered by DJS Bacau

In 2011, in Romania there was a negative balance of the foreign trade operations amounting to $9,782,786$ thousand Euro. The highest negative balance was recorded in the region Bucharest-Ilfov $(-11,478,022$ thousand Euro) followed, at great distance, by the South-East region (-876,683 thousand Euro) and the North-East region (-165,915 thousand Euro). It can be noticed that in the other 5 regions the value of exports was higher than the value of the imports, the greatest surplus of the trade balance being recorded in South Muntenia $(+1,265,630$ thousand Euro), followed by the West region ( $+629,215$ thousand Euro), SouthWest Oltenia $(+421,302$ thousand Euro), the Central region $(+213,809$ thousand Euro) and the North-West ( $+141,788$ thousand Euro).

Alongside the trade balance, the import/export coverage ratio is another index which shows the efficiency of foreign trade. On the level of the whole country, the degree of import/export coverage ratio in 2011 was of $82,2 \%$, a lower coverage ratio being recorded only in the Bucharest-Ilfov region. Consequently, the lowest coverage ratio, situated beyond the national average, was recorded in Bucharest-Ilfov (43.8\%), while above the national average and below $100.0 \%$ were the South-East $(84.4 \%)$ and the North-East $(92.2 \%)$ regions. South-West Oltenia is on the first place in the hierarchy of the regions with the highest coverage ratio $(123.0 \%)$, the second place belonging to South Muntenia $(119.9 \%)$, and the third position to the West region $(110.6 \%)$; on the next two places are the Central $(103.8 \%)$ and the NorthWest $(102.1 \%)$ regions.

After analyzing figures 2 and 4 , we can notice that $52.6 \%$ of the total amount of exports, and $61.5 \%$ of the total amount of imports, were recorded in only 3 regions; thus, we may ask if there is a spatial concentration of the foreign trade into certain regions of the country. 


\section{The degree of spatial concentration of the international trade in Romania}

In order to express in figures this phenomenon of international trade spatial concentration in Romania, I analyzed the export and the import spatial concentration on different regions of Romania.

A first analysis implied building the Lorentz-Gini curve for concentration and, based on it, calculating the degree of concentration by determining a certain coefficient - the Gini index. The clustering curves for the export and the import respectively are not close to the diagonal of the square, which proves that there is a regional concentration of these trade fluxes, fact also proved by the values calculated for the concentration indexes. The Gini index for export concentration, calculating using the trapeze method, is $22.4 \%$, lower than the one calculated for the imports, which is $30.1 \%$, which means that there is an average concentration of the regions into certain groups of values, for the exports as well as for the imports.

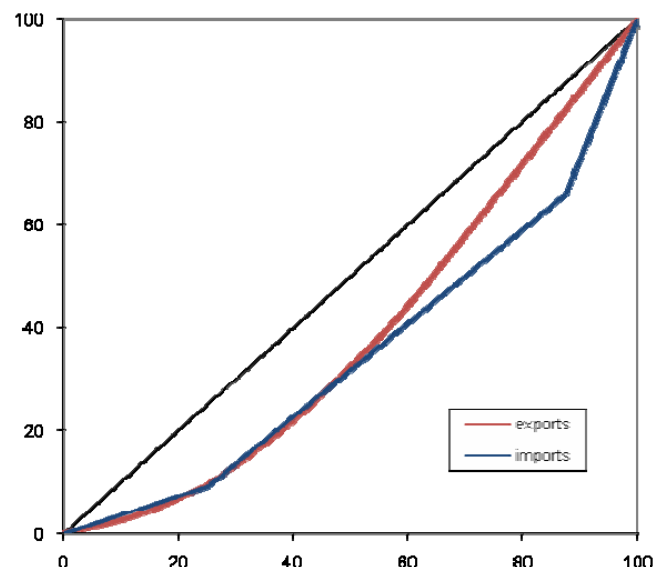

Figure 6. The concentration curve for the exports and the imports in 2011

Source: processing of the data offered by DJS Bacau

Another analysis, complementary to the one presented above, involves building a boxplot for each trade flow, exports and imports, according to the distribution on the development regions (for this type of analysis, I used the statistical analysis programme SPSS).

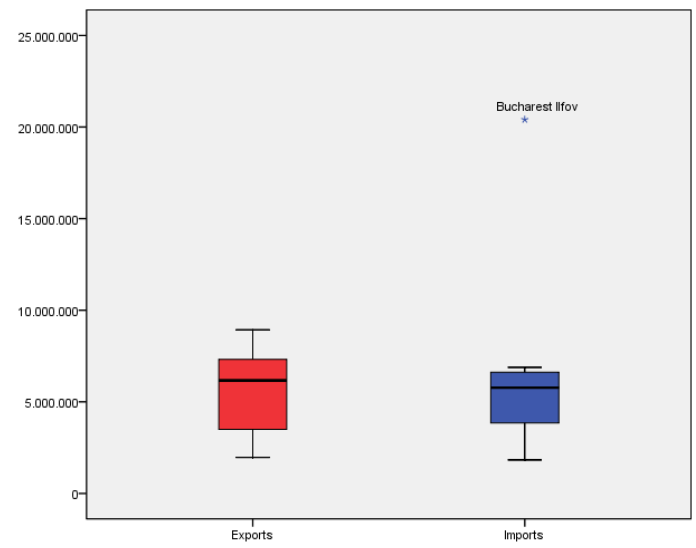

Figure 7. Boxplot for the regional distribution of the exports and imports in 2011 Source: processing of the data offered by DJS Bacau 
It can be noticed that for the exports as well as for the imports, the spatial concentration of regions tend towards the high values of the exports or of the imports respectively, and that there are no differences between the trade flows concerning the values of the exports and of the imports for the 1, 2 and 3 quartiles; there is a significant difference only between the maximum values of the series (excluding the outliners). At the same time, this graphical representation emphasizes the fact that Bucharest-Ilfov is an outlier for the series of data pertaining to the imports; in other words, this region differs from the other regions when it comes to the value of the imports.

\section{Conclusions}

Romania's foreign trade in 2011 revolves mainly around the Bucharest-Ilfov region, and on regional level there is a spatial concentration of trade fluxes.

\section{Bibliografie}

1. Harja E. (2009), Statistică, Ed. Matrix Rom, Bucureşti

2. Jaba E. (1998), Statistică, Ed. Economică, Bucureşti

3. Pascariu G.C., Frunză R., Stângaciu O.A. (2010), Foreign Trade of Romania - a regional perspective, Working papers Series - Centrul de Studii Europene, Vol. II, nr. 1, Iași

4. Stângaciu O.A. (2010), Romania's foreign trade in 2008 - a territorial analysis, Studii şi cercetări științifice - Seria: Științe Economice, Facultatea de Științe Economice, Universitatea Bacău, nr. 1 (15)

5. Voineagu V. şi colaboratorii (2001), Statistică economică, Ed. Tribuna Economică, București

6. Colecţia Anuarul de comert exterior al României, Institutul Naţional de Statistică, Bucureşti

7. Colecţia Buletinul Statistic Lunar al județelor, Institutul Naţional de Statistică, Bucureşti

8. Data offered by DJS Bacau 